\title{
PSORIASIS PUSTULOSA GENERALISATA PADA REMAJA YANG DITERAPI DENGAN INJEKSI METOTREKSAT
}

\author{
Sri Esa Ilona, Muh. Eko Irawanto \\ Bagian/SMF Ilmu Kesehatan Kulit dan Kelamin RSUD dr. Moewardi \\ FK Universitas Sebelas Maret, Surakarta
}

\begin{abstract}
ABSTRAK
Psoriasis adalah penyakit inflamasi seluler kronis, sering pada anak-remaja (usia <18 tahun) dan dewasa. Prevalensi psoriasis anak-remaja adalah sekitar 0-1,37\%. Psoriasis pustulosa termasuk psoriasis pustulosa generalisata (PPG) sangat jarang pada anak-remaja. Gambaran klinisnya hampir sama dengan dewasa. Metotreksat (MTX) merupakan terapi lini pertamanya yang aman.

Seorang remaja, 16 tahun, muncul bercak merah dan bintil bernanah di seluruh tubuh. Pertama kali muncul saat pasien berusia 3 bulan. Kemudian muncul kembali 4 bulan dan 2 minggu yang lalu, tidak ada demam maupun gigi berlubang. Riwayat alergi dan keluarga sakit serupa tidak ada. Status dermatologis regio generalisata tampak pustul multipel diskret sebagian konfluens (lake of pustule) dengan dasar eritem dan krusta di atasnya. Pemeriksaan laboratorium ditemukan netrofilia dan hipernatremia. Pemerikaan histopatologi pada epidermis tampak psoriasiform dan sebukan netrofil disertai kelompok netrofil pada subkorneal.

Diagnosis PPG pada kasus ini ditegakkan berdasarkan pemeriksaan klinis dan histopatologi. Terapi MTX terutama untuk psoriasis sedang-berat; peroral, subkutan/intradermal dan relatif murah. Saat ini belum ada panduan pengobatan dan dosis MTX untuk anak-remaja. Metotreksat pada pasien ini diberikan seperti pada dewasa. Tolerabilitas dan efikasinya pada anak-remaja dilaporkan pada beberapa laporan kasus, termasuk dari kasus ini walaupun masih memerlukan pemantauan lebih lanjut.
\end{abstract}

Kata kunci: metotreksat, psoriasis pustulosa generalisata pada anak-remaja

\section{ADOLESCENT GENERALIZED PUSTULAR PSORIASIS TREATED WITH METOTREXATE INJECTION}

\section{Korespondensi:}

Alamat: Jl. Kol. Soetarto No. 132, Surakarta

Telp/fax: 0271-634848

Email: $\underline{\text { rriesailona ai@yahoo.com }}$

\begin{abstract}
Psoriasis is a chronic, T-cell-mediated-inflammatory disease, commonly in children-adolescent (age $<18$ years) and adults. The prevalence of children-adolescent psoriasis is $0-1.37 \%$, very rare in generalized pustular psoriasis (GPP). Clinically GPP in $<18$ years-old is similar to adults. Methotrexate is the safefirst-line therapy option.

A 16-year-old girl complaints of pustule on eritematous base all over the body. Similar complaints appeared when she was 3-months-old. Then reappeared 4 months and 2 weeks before admission. There were no fever or carries-dentis. Allergy and family history were denied. Dermatological examination showed multiple discrete pustules with some lake of pustule on an erythematous-base and crust on it. From laboratory examination showed neutrophilia and hypernatremia. Histopathological examination of epidermis showed psoriasiform and discrete neutrophils with a grouped neutrophil on the subcorneal layer.

The diagnosis of chidren-adolescent GPP like this case is established based on clinical and histopathological examination. Methotrexate especially for moderate-severe psoriasis, administered orally, subcutaneously/intradermally, and relatively cheap. Until now there is no treatment guidelines and doses regimen for methotrexate in children-adolescent. Methotrexate in this patient give as that adult. Tolerability and efficacy in children-adolescent have been reported from several literature as well as from this case, although the patient still needs monitoring and further follow-up.
\end{abstract}

Key words: Erythema Nodosum Leprosum (ENL), pentoxifylline, leprosy, vasculonecrotic 


\section{PENDAHULUAN}

Psoriasis adalah penyakit inflamasi seluler kronis yang mengenai kulit, kuku dan atau persendian, sering ditemui pada dua kelompok usia yaitu anak - remaja (usia $<18$ tahun) dan dewasa. Penyakit ini diperkirakan mengenai 2,0-3,5\% populasi dunia. ${ }^{1}$ Hampir sepertiganya terdiagnosis pertama kali pada usia $<18$ tahun yaitu pada usia 6,6-7,6 tahun. ${ }^{1,2}$ Prevalensi psoriasis pada kelompok usia $<8$ tahun adalah sekitar $0-1,37 \%$, dengan tipe psoriasis yang sering terjadi adalah psoriasis plak dan psoriasis gutata. Sedangkan psoriasis pustulosa sangat jarang terjadi yaitu hanya 1,0-5,4 \% dari seluruh pasien psoriasis anak - remaja.,

Psoriasis pustulosa merupakan salah satu bentuk psoriasis yang memiliki beberapa varian yaitu: psoriasis pustulosa generalisata (PPG)/von Zumbusch, psoriasis pustular anularis, psoriasis pustular eksantem dan psoriasis pustular lokalisata. ${ }^{5,6}$ Keempat bentuk psoriasis pustulosa ini dapat ditemukan pada orang dewasa maupun anak - remaja dengan perbedaan distribusi, morfologi dan gejala klinisnya. ${ }^{1,4}$ Walaupun demikian, diagnosis PPG tetap dapat ditegakkan berdasarkan gambaran klinis dan didukung dengan pemeriksaan histopatologi. ${ }^{7}$ Diagnosis harus segera ditegakkan karena psoriasis pada anak maupun remaja berdampak cukup besar pada kesehatan psikologis dan sering disertai komorbid seperti obesitas, hipertensi, hiperlipidemia, diabetes melitus dan artritis reumatoid.

Sampai saat ini belum ada panduan terapi standar psoriasis pada anak - remaja. ${ }^{1,8}$ Secara umum, manajemen terapi PPG pada usia anak - remaja yaitu terapi topikal dan pengendalian faktor pencetus dengan tujuan menurunkan terjadinya kekambuhan. Terapi sistemik baik terapi biologik maupun non-biologik diberikan terutama untuk psoriasis plak yang berat, psoriasis nonstabil (eritroderma psoriatika dan PPG), psoriasis artritis dan yang tidak respons terhadap terapi topikal. ${ }^{8,9}$ Terapi sistemik yang dapat digunakan pada psoriasis anak - remaja yaitu asitretin, retinoid, metotreksat (MTX) dan siklosporin. ${ }^{8,10}$ Pada beberapa literatur dikatakan bahwa MTX adalah terapi yang aman dan pilihan terapi lini pertama untuk pasien PPG usia $<$ 18 tahun. $^{8,11-13}$ Respons PPG usia tersebut terhadap MTX lebih cepat (4,5 minggu) dibandingkan psoriasis plak (5 minggu) dan bentuk rupioid (13 minggu), namun tetap diperlukan pemantauan dan follow up rutin. ${ }^{11}$

Pada makalah ini dilaporkan satu kasus PPG pada seorang anak berusia 16 tahun yang diterapi dengan injeksi MTX. Tujuan pelaporan kasus ini adalah melaporkan kasus jarang yang terjadi pada remaja dan penggunaan MTX pada remaja sehingga dapat menambah wawasan mengenai penyakit ini dan terapi MTX pada remaja.

\section{KASUS}

Seorang anak perempuan berusia 16 tahun, datang ke instalasi gawat darurat (IGD) RS. Dr. Moewardi (RSDM) pada tanggal 22 Mei 2017 dengan keluhan muncul bercak merah dan bintil bernanah di seluruh tubuh sejak 2 minggu yang lalu. Keluhan serupa pertama kali muncul saat pasien berusia 3 bulan. Pasien dibawa berobat ke dokter spesialis kulit dan kelamin oleh orang tuanya, sembuh dan tidak pernah kambuh hingga 4 bulan yang lalu pasien mengeluh muncul keluhan yang sama, namun pasien tidak berobat ke dokter. Pasien membeli obat sendiri di apotek yaitu mikoral ${ }^{\circledR}$ tablet $1 \times 1$ selama 14 hari dan 1 macam obat oles yang pasien lupa namanya. Dua minggu sebelum masuk rumah sakit ketika pulang dari acara perkemahan, pasien mengeluh muncul kembali bercak merah dan bintil putih, awalnya di paha kemudian semakin meluas ke seluruh tubuh. Bercak merah tersebut tidak gatal dan tidak nyeri. Satu hari sebelum masuk rumah sakit keluhan dirasa semakin berat, kemudian pasien berobat jalan ke Rumah Sakit Univeritas Sebelas Maret dan mendapat terapi sinar namun keluhan semakin bertambah banyak sehingga pasien dibawa ke RSDM. Keluhan tidak disertai dengan demam. Pasien tidak mempunyai gigi berlubang, riwayat alergi dan riwayat sakit serupa dalam keluarga.

Pada pemeriksaan fisik didapatkan keadaan umum baik, kesadaran kompos mentis, kesan gizi cukup, pemeriksaan fisik dalam batas normal, tidak didapatkan pembesaran kelenjar getah bening regional dan skor nyeri skala 2-3. Status dermatologis pada regio generalisata tampak pustul multipel diskret sebagian konfluen membentuk lake of pustule dengan dasar eritem dan krusta di atasnya (Gambar 1). Diagnosis banding kasus ini adalah psoriasis pustular generalisata dan pustulosis eksantematosa generalisata akut (PEGA). 

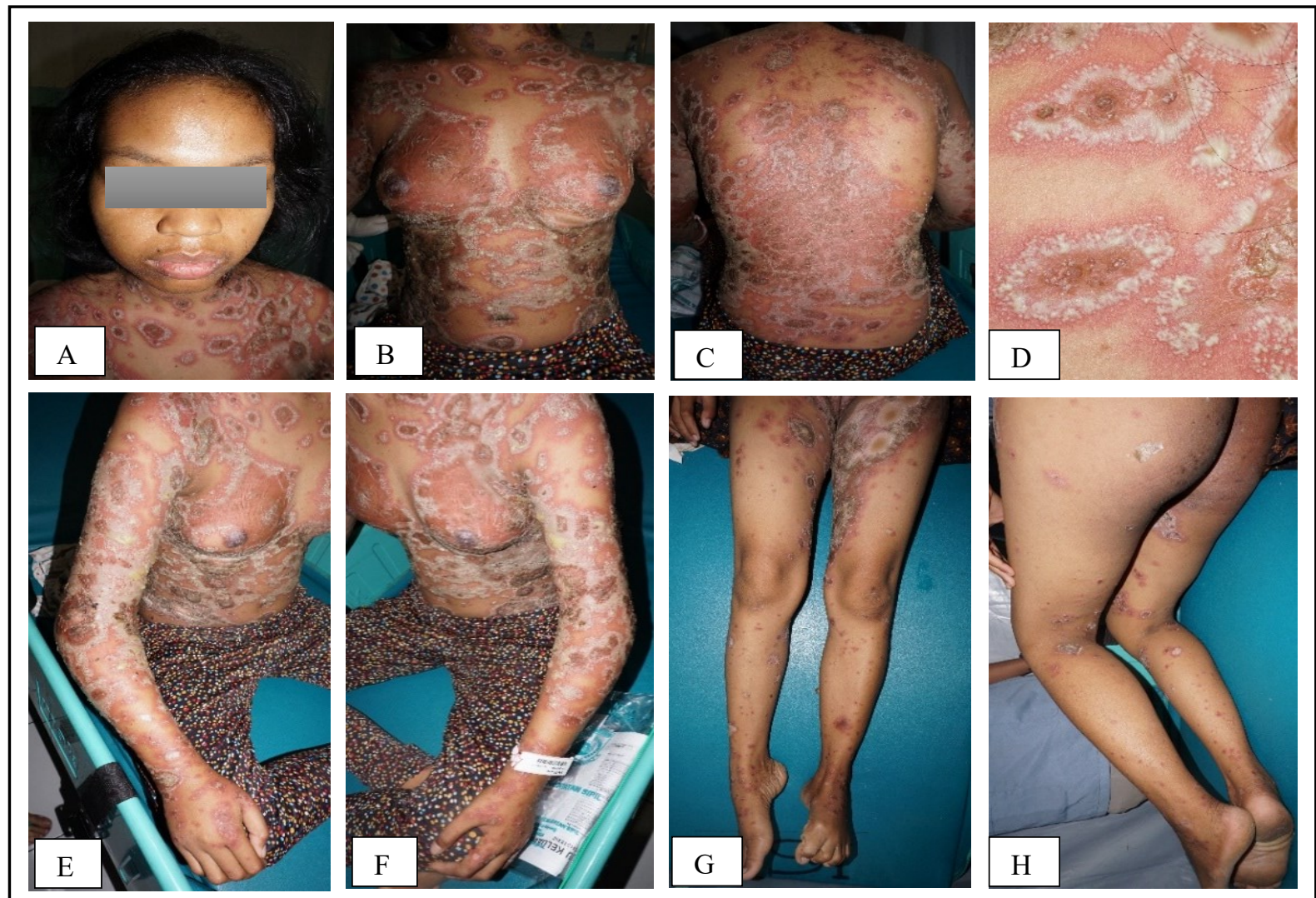

Gambar 1 (A-H). Foto Pasien saat datang ke IGD RSDM. Regio generalisata tampak pustul multipel diskret sebagian konfluen membentuk lake of pustule dengan dasar eritem dan krusta di atasnya.

Untuk menegakkan diagnosis, dilakukan pemeriksaan laboratorium, pewarnaan Gram dan biopsi kulit. Pada pemeriksaan laboratorium, didapatkan lekosit meningkat (25,4 ribu/ul / $\mathrm{N}=4,5-14,5 \mathrm{ribu} / \mathrm{ul})$; peningkatan netrofil $(84,30 \% / \mathrm{N}=29-72 \%)$ dan monosit $(8,30 \% / \mathrm{N}=0-6$ $\%)$, penurunan limfosit $(6,80 \%$ / $\mathrm{N}=33-48 \%)$; glukosa darah sewaktu sedikit meningkat $(117 \mathrm{mg} / \mathrm{dl} / \mathrm{N}=60-100$ $\mathrm{mg} / \mathrm{dl})$; pembekuan darah, fungsi hepar dan ginjal dalam batas normal; penurunan natrium $(131 \mathrm{mmol} / \mathrm{L} / \mathrm{N}=132$ $145 \mathrm{mmol} / \mathrm{L})$ dan kalsium $(1,11 \mathrm{mmol} / \mathrm{L} / \mathrm{N}=1,17-1,29$ $\mathrm{mmol} / \mathrm{L}$ ). Pada pemeriksaan Gram didapatkan polimononuklear 5-10 / lapang pandang besar (LPB), kokus gram positif 50-100 / LPB, batang gram negatif 20 -30 / LPB. Pada tanggal 29 Mei 2017 dilakukan biopsi plong pada lesi di tungkai bawah kiri. Jaringan diwarnai dengan Hematoxilin Eosin (HE) didapatkan hasil pada epidermis tampak psoriasiform dan sebukan sel lekosit polimorfonuklear (PMN) yaitu sel netrofil disertai kelompok leukosit PMN subkorneal. Jaringan subepidermal sembab dengan sebukan ringan leukosit PMN. Kesimpulan dari pemeriksaan histopatologi yaitu dapat menyokong diagnosis PPG (Gambar 2). Sehingga berdasarkan anamnesis, pemeriksaan fisik, dan histopatologi diagnosis pasien ini adalah PPG.

Penatalaksanaan untuk pasien tersebut yaitu rawat inap, diet TKTP $1700 \mathrm{kkal}$, infus RL 20 tetes / menit, injeksi MTX $5 \mathrm{mg}$ (test dose), injeksi Ranitidin $50 \mathrm{mg} /$ 12 jam, kompres dengan $\mathrm{NaCl} 0,9 \%$ kemudian dioles salap desoksimetason sehari. Pasien dirawat selama 10 hari kemudian kontrol setiap minggu ke poli kulit dan kelamin. Karena lesi baru selalu muncul maka dosis MTX dari dosis terapi $10 \mathrm{mg} /$ minggu dinaikkan menjadi 15 $\mathrm{mg} /$ minggu pada kontrol yang ketiga. Pada saat kontrol yang keempat pasien flare saat pasien baru saja selesai ujian semester. Kemudian pasien dirawat inap kembali selama 1 minggu. Pemeriksaan laboratorium darah rutin, gula darah, fungsi hati dan ginjal didapatkan hasil dalam batas normal. Tata laksana pasien selanjutnya yaitu pasien akan terus dipantau terutama untuk mendapatkan dosis MTX terkontrol. 


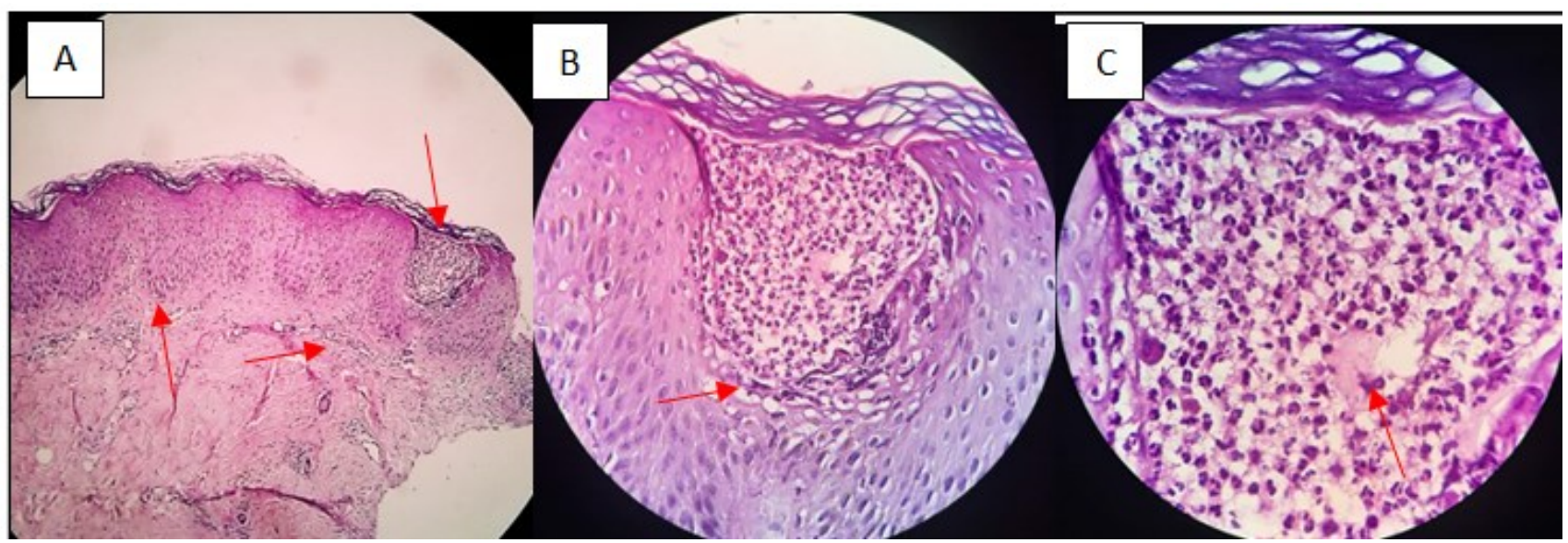

Gambar 2 (A-C). Pemeriksaan histopatologi dengan pewarnaan HE. Sediaan diambil dari lesi pada tungkai bawah. (A) Pada pembesaran 40x. tampak psoriasiform (panah keatas) dan kelompok leukosit PMN pada subkorneal (panah kebawah). Jaringan subepidermal sembab, dengan sebukan ringan leukosit PMN (panah kesamping). (B) Pembesaran 100x tampak kumpulan sel leukosit PMN subkorneal. (C) Pembesaran 1000x. tampak kumpulan sel leukosit PMN yaitu sel netrofil, tidak ada eosinofil.

\section{PEMBAHASAN}

Psoriasis pustulosa generalisata adalah salah satu bentuk psoriasis pustulosa yang akut, episodik dan berpotensi mengancam jiwa. ${ }^{4}$ Psoriasis pustulosa sangat jarang terjadi pada usia $<18$ tahun. ${ }^{1,4}$ Onset penyakit ini mulai dari usia 1 bulan sampai 11 tahun, rata-rata ditemukan pada usia 6,6 tahun untuk anak laki - laki dan 5,5 tahun untuk anak perempuan. ${ }^{4}$ Pada remaja PPG lebih sering terjadi pada laki - laki. ${ }^{2}$ Etiologi dan patogenesis psoriasis pustulosa pada kelompok usia $<18$ tahun sampai saat ini belum diketahui. Sekitar $30 \%$ pasien tersebut mempunyai riwayat orang tua dengan psoriasis. Psoriasis pada usia ini juga berhubungan dengan faktor pencetus seperti infeksi, vaksinasi, withdrawal kortikosteroid, stres psikososial, obesitas dan berbagai faktor eksaserbasi seperti trauma maupun iritasi pada kulit akibat penggunaan obat litium, antagonis $\beta$-adrenergik dan inhibitor tumor necrosis factor alpha. ${ }^{1,2}$

Diagnosis psoriasis pada usia anak-remaja dapat ditegakkan berdasarkan gambaran klinis (morfologi dan distribusi lesi). Karakteristik klasik lesi PPG dapat ditemui pada kelompok usia ini berupa pustul steril yang tersebar generalisata di atas kulit yang eritem dan mengalami resolusi dalam 3 - 4 hari, dengan masa inflamasi yang berulang, biasanya disertai demam dan toksisitas. ${ }^{4}$ Lesi PPG pada anak - remaja sering difus dan berbentuk sirsinar atau anular, ${ }^{1,2,7}$ dapat disertai komplikasi pada tulang berupa lesi litik steril dan dapat bermanifestasi menjadi sindrom SAPHO (sinovitis, akne, pustulosis, hiperostosis dan osteitis). ${ }^{6}$

Pada PPG tidak ada pemeriksaan laboratorium yang spesifik. ${ }^{7}$ Pada pemeriksaan darah lengkap dan kimiawi dapat ditemukan adanya peningkatan laju endap darah, ${ }^{14}$ leukositosis dengan netrofilia, gangguan elektrolit, ginjal dan hepar, ${ }^{7}$ serta hipokalsemia. ${ }^{5}$ Pada pemeriksaan sediaan apus pustul tidak didapatkan bakteri Gram positif ataupun Gram negatif. ${ }^{6,7}$ Pemeriksaan laboratorium juga digunakan untuk mencari faktor komorbid pada pasien dan evaluasi pengobatan yang telah diberikan.,

Biopsi kulit hampir tidak pernah dilakukan pada anak-remaja. Namun jika gambaran klinis tidak khas maka biopsi kulit dapat membantu memastikan diagnosisnya. ${ }^{1}$ Gambaran histopatologi psoriasis pada epidermis tampak parakeratosis, akantolitik, pemanjangan rete ridges, kumpulan netrofilik (mikroabses munro), pada dermis tampak pembuluh darah melebar dan infiltrat limfositik perivaskular. ${ }^{15}$ Karakteristik ini dapat bervariasi bergantung pada perjalanan penyakit, lokasi biopsi, subtipe psoriasis dan apakah pasien telah diobati dengan obat topikal dan atau sistemik sebelumya. ${ }^{1,15}$

Kasus ini didiagnosis banding dengan PEGA, yaitu suatu reaksi kulit yang parah, ditandai dengan pembentukan pustul steril nonfolikular akut dengan dasar eritematosa disertai demam dan netrofilia yang biasanya berhubungan dengan obat. ${ }^{16,17}$ Pada anak-remaja PEGA juga merupakan penyakit kulit yang sangat jarang terjadi. Pada beberapa laporan PEGA pada anak-remaja terjadi akibat obat (amoksisilin, vankomisin, ribavirin, labetolol dan lain-lain), infeksi virus (Virus Coxsackie B4, Virus Epstein-Barr), dan vaksin pneumococcus. Jarak waktu dari minum obat sampai muncul lesi kulit biasanya 2 - 3 hari untuk antibiotik dan 3-18 hari untuk selain antibiotik. ${ }^{18}$ Gambaran histopatologi PEGA yaitu terdapat pustul netrofilik pada lapisan korneum dan atau epidermis dengan spongiosis dan akantolisis minimal, pada dermis terdapat sebukan sel limfosit dan eosinofil. ${ }^{19}$ Gambaran histopatologi PEGA kadang sangat mirip dengan PPG. Dibandingkan dengan PPG, PEGA dapat sembuh spontan jika obat sudah dieliminasi, resolusi biasanya terjadi 
dalam waktu singkat, tidak mengalami rekurensi, dan tidak ada keluhan artritis. ${ }^{16,19}$

Sementara pasien pada kasus ini, dari anamnesis didapatkan bahwa pasien tidak demam, tidak menderita penyakit infeksi, tidak ada riwayat minum obat. Menurut keluarga, pasien sudah pernah menderita sakit serupa saat berusia 3 bulan dan baru muncul lagi 1 bulan yang lalu, dan saat masuk lesi kulit semakin meluas. Dari pemeriksaan fisik didapatkan lesi generalisata berbentuk anular dengan pustul steril di atas kulit yang eritem; dari pemeriksaan laboratorium didapatkan lekositosis dengan netrofilia dan hipernatremia; dan dari pemeriksaan histopatologi tampak psoriasiform pattern minimal namun tidak dijumpai adanya sel eosinofil. Sehingga berdasarkan hasil pemeriksaan klinis dan pemeriksaan penunjang tersebut diagnosis pasien ini adalah PPG. Selama masa perawatan pasien beberapa kali mengalami flare. Saat ini pasien terapi dengan MTX $15 \mathrm{mg} / \mathrm{minggu}$.

Metotreksat adalah antimetabolit yang memodulasi sistem imun dan proses inflamasi, merupakan obat yang sering diresepkan untuk psoriasis di seluruh dunia terutama di negara berkembang. ${ }^{12}$ Berdasarkan evidence base, MTX merupakan pilihan pengobatan sistemik yang aman untuk psoriasis sedang - berat pada anak-remaja yang dapat diberikan secara oral, subkutan maupun intradermal dan relatif murah. ${ }^{8,11,12}$ Penggunaan MTX pada anak-remaja awalnya ditetapkan untuk psoriasis plak namun selanjutnya digunakan juga untuk psoriasis ekstensif, rekalsitran, berat, resisten terhadap terapi topikal dan fototerapi, psoriasis eritrodermik maupun PPG. ${ }^{20}$

Sampai saat ini belum ada rejimen pengobatan dan dosis MTX untuk anak-remaja. ${ }^{111}$ Tolerabilitas dan efikasinya pada anak usia tersebut telah dilaporkan dari beberapa laporan kasus. Kebanyakan MTX digunakan dengan dosis $0,2-0,4 \mathrm{mg} / \mathrm{kgbb} / \mathrm{minggu}$ namun ada juga yang menggunakan dosis rendah 0,003-0,24 mg/kgbb/ minggu kemudian dinaikkan menjadi $0,1-0,41 \mathrm{mg} / \mathrm{kgbb} /$ minggu. ${ }^{12}$ Napolitano dkk. menetapkan dosis MTX untuk anak-remaja adalah 0,2-0,7 mg/kgbb/minggu karena telah menunjukkan efektifitas dan manfaatnya, kemudian dosis dinaikkan 1,25-5 mg/minggu sampai didapatkan perbaikan klinis. ${ }^{8}$ Ketika dicapai dosis terapi terkontrol (PASI 75) dianjurkan untuk segera menurunkan dosis ke dosis perawatan yang efektif atau lebih rendah untuk mengurangi efek samping MTX. ${ }^{1}$ Pasien pada kasus ini masih belum didapatkan dosis terkontrolnya.

Efek samping MTX pada psoriasis kelompok usia $<18$ tahun biasanya dapat diatasi dengan baik. ${ }^{13}$ Efek samping yang paling umum terjadi yaitu mual, muntah, kelelahan, stomatitis dan abnormalitas tes fungsi hati. Penekanan sumsum tulang, toksisitas paru, infeksi dan hepatotoksik termasuk fibrosis hati jarang dilaporkan terjadi pada anak-remaja. Penekanan sumsum tulang berpotensi mengancam jiwa, dan umumnya terjadi dalam bulan pertama pengobatan. Pemeriksaan laboratorium harus dilakukan secara berkala untuk memantau hal tersebut. Selain itu, perlu dihindari penggunaan secara simultan obat anti-inflamasi nonsteroid dan trimetoprim/ sulfa-metoksazol karena dapat berinteraksi dengan MTX dan meningkatkan potensi toksisitasnya. $^{1,8}$ Selain pemantauan rutin, untuk mencegah terjadinya efek samping dan meningkatkan efikasi, MTX sebaiknya dikombinasikan dengan terapi topikal dan atau fototerapi, ${ }^{8}$ serta asam folat. ${ }^{21}$

\section{SIMPULAN}

Telah dilaporkan satu laporan kasus PPG pada pasien anak perempuan berusia 16 tahun. Diagnosis ditegakkan berdasarkan anamnesis, pemeriksaan fisik dan histopatologi. Pasien diterapi dengan injeksi MTX dengan dosis $15 \mathrm{mg} / \mathrm{minggu}$. Sampai saat ini masih belum dicapai dosis terkontrol. Metotreksat merupakan salah satu pilihan terapi lini pertama yang aman untuk PPG pada anak dan remaja. Walaupun efek samping jarang terjadi pada usia tersebut begitu juga pada pasien ini tetap diperlukan pemantauan yang bersinambungan.

\section{DAFTAR PUSTAKA}

1. Bronckers IMGJ, Kerkhof PCMvd, Paller AS, Geel MJv, Seyger MMB. Psoriasis in children and adolescents: Diagnosis, management and comorbidities. Pediatr Drugs. 2015;17:373-84.

2. Benjegerdes KE, Hyde K, Kivelevitch D, Mansouri B. Pustular psoriasis: Pathophysiology and current treatment perspectives. Dovepress. 2016;6:131-44.

3. Michalek IM, Loring B, John SM. A systematic review of worldwide epidemiology of psoriasis. J Eur Acad Dermatol Venereol. 2016;31:1-8.

4. Oliveira STd, Maragno L, Arnone M, Takahashi MDF, Romiti R. Generalized pustular psoriasis in childhood. Pediatr Dermatol. 2010;27:349-54.

5. Raychaudhuri SK, Maverakis E, Raychaudhuri SP. Diagnosis and classification of psoriasis. Autoimmun Rev. 2014;13:490-5.

6. Gudjonsson JE, Elder JT. Psoriasis. Dalam: Wolff K, Goldsmith LA, Katz SI, Gilchrest BA, Paller AS, Leffell DJ, penyunting. Fitzpatrick's Dermatology in General Medicine. Edisi ke-8. New York: McGraw Hill Companies; 2012.h. 197231.

7. Tollefson MM. Diagnosis and management of psoriasis in children. Pediatr Clin N Am. 2014;61:261-77.

8. Napolitano M, Megna M, Balato A, Ayala F, Lembo S, Villani A, dkk. Systemic treatment of pediatric psoriasis: A review. Dermatol Ther (Heidelb). 2016;6:125-42.

9. Saikaly SK, Mattes M. Biologics and pediatric generalized pustular psoriasis: An emerging therapeutic trend. J Med Sci. 2016;8:1-8.

10. Dogra S, Mahajan R, Narang T, Handa S. Systemic cyclosporine treatment in severe childhood psoriasis: A retrospective chart review. J Dermatolog Treat. 2016;28:1-3. 
11. Tarang Goyal SP, Varshney A. The study of clinical outcome of systemic methotrexate uses in moderate to severe childhood psoriasis. Indian J Paediatr Dermatol 2017;18:31-5.

12. Dogra S, Mahajan R. Systemic methotrexate therapy for psoriasis: past, present and future. Clin Exp Dermatol. 2013;38:573-88.

13. Jager MEAd, Jong EMGJd, Kerkhof PCMvd, Seyger MMB. Efficacy and safety of treatments for childhood psoriasis: A systematic literature review. J Am Acad Dermatol. 2010;62:1013-30.

14. Griffith CEM, Camp HI, Baker J. Psoriasis. Dalam: Burn T, Breathnach S, Cox N, Griffith CEM, penyunting. Rook's textbook of dermatology. Edisi ke-7. Massachussets: Blackwell Publishing; 2004.h. 351-69.

15. Weedon D. Pustular psoriasiform. Dalam: The psoriasiform reaction pattern. Weedon's Skin Pathology. Edisi ke-3. Edinburgh: Churchill Livingstone/Elsevier's; 2010.h. 81-3.

16. Feldmeyer L, Heidemeyer K, Yawalkar N. Acute generalized exanthematous pustulosis: Pathogenesis, genetic background, clinical variants and therapy. Int $\mathrm{J}$ Mol Sci. 2016;17:1-9.

17. Szatkowski J, Schwartz RA. Acute generalized exanthematous pustulosis (AGEP): A review and update. J Am Acad Dermatol. 2015;73:843-8.

18. Sezer E, Sezer T, Dogankoseoglu, Onukfiliz N. Acute generalized exanthematous pustulosis in a child. Pediatr Dermatol. 2007;24:93-5

19. Kardaun SH, Kuiper H, Fidler V, Jonkman MF. The histopathological spectrum of acute generalized exanthematous pustulosis (AGEP) and its differentiation from generalized pustular psoriasis. J Cutan Pathol. 2010;37:1220-9.

20. Fotiadou C, Lazaridou E, Ioannides D. Management of psoriasis in adolescence. Adolesc Health Med Ther.2014;5:25-34.

21. Al-Dabagh A, Huang K, Davis SA, Feldman SR, Kinney MA. The effect of folate supplementation on methotrexate efficacy and toxicity in psoriasis patients and folic acid use by dermatologists in the USA. Am J Clin Dermatol. 2013;14:155-61. 